\title{
Comparative digestion of herbage by two breeds of sheep: effects of grass maturity stage and level of intake
}

\author{
S. López†, P. Frutos, A. R. Mantecón and F. J. Giráldez \\ Estación Agrícola Experimental, CSIC, Apartado 788, 24080 León, Spain \\ + Present address: Departamento de Producción Animal, Universidad de León, 24071 León, Spain; \\ e-mail: DP1SLP@isidoro.unileon.es
}

\begin{abstract}
Two trials were conducted to study the effect of the stage of maturity of fresh herbage on its digestibility by two breeds of sheep (Churra v. Merino). The sward consisted of a mixture of grasses and clover, and was harvested either in late May (early cut, EC) or in late July (late cut, LC). In each trial, 12 mature sheep of each breed were used. Each animal received a different amount of fresh herbage, so that levels of food intake ranged between 8.1 and $24.7 \mathrm{~g}$ dry matter (DM) per $\mathrm{kg}$ body weight per day. EC herbage showed higher crude protein content (116 v. $67 \mathrm{~g} / \mathrm{kg}$ DM), lower neutral-detergent fibre concentration (494 v. $664 \mathrm{~g} / \mathrm{kg}$ DM) and higher DM digestibility (0.687 (s.e. $0.005)$ v. 0.463 (s.e. 0.007)) than the LC herbage. DM digestibility coefficients observed in Churra (0.694 (s.e. 0.028 ) for EC and 0.476 (s.e.0.028) for LC herbage) tended to be greater than those observed in Merino sheep $(0.680$ (s.e.0.021) for EC and 0.452 (s.e.0.040) for LC herbage). With the EC herbage DM digestibility tended to decrease as the level of intake increased. Samples of dried herbage were incubated in the rumen of Churra and Merino sheep to determine the DM degradability by the in situ technique. Fractional degradation rates (c values) were significantly faster in the mumen of Churra than in Merino (0.046 (s.e. 0.003) v. 0.031. (s.e. 0.002)), with large differences between breeds in the DM disappearance rates at intermediate incubation times, and no significant differences between Churra and Merino sheep in the mean $a+b$ values. Microbial $N$ supply, calculated from the urinary excretion of purine derivatives, was significantly affected by the herbage maturity stage and by the level of DM intake, but not by the breed of sheep. It is suggested that differences between breeds of sheep in food digestibility may be related to their ability to digest fibrous diets.
\end{abstract}

Keywords: digestibility, food intake, herbage, rumen digestion, sheep breeds.

\section{Introduction}

Comparative studies have shown differences between ruminant species in the utilization of roughage diets, most likely related to differences in their feeding behaviour and digestive processes (Dulphy et al., 1995). These differences have been observed even between breeds within the same species and may represent distinct feeding strategies as the result of the adaptation for survival in their characteristic natural environment (Van Soest, 1994). Such breed differences have important implications for the suitability of particular genotypes for lowinput extensive systems of animal production, and within-species variation needs to be evaluated, as findings in one breed may not be applicable across the whole species.

The two main sheep breeds in northern Spain are Churra and Merino. They have been traditionally managed in different grazing systems based on the use of natural resources (stubble, mountain pasture, etc.): the Merino breed has been managed in a transhumance regime and the Churra breed has been used in semi-arid upland areas as part of a nonmigratory system (Frutos et al., 1998). It is possible that these different regimes have pushed these breeds to evolve different digestive mechanisms. 
Some comparative studies have reported differences between Churra and Merino breeds in the weights of different parts of the digestive tract (Frutos et al., 1992), diet selection when grazing on a hill shrub community (Revesado et al., 1994), voluntary intake of forages (Amor, 1994) and ruminal activity (Ranilla et al., 1997). Rumen degradability of various foods was higher in Churra than in Merino sheep and differences between both breeds were greater with foods with a higher cell wall content (Ranilla et al., 1997). However, no differences were found in digestibility when animals were given a good-quality forage (Ranilla et al., 1998). It has been suggested that the magnitude of the differences between breeds may be variable depending on the diet and the level of intake (Ranilla et al., 1998; Lourenço et al., 2000).

This study was carried out to examine the differences between Churra and Merino sheep in the digestibility and rumen degradation of fresh herbage harvested at two maturity stages, and offered over a wide range of levels of intake.

\section{Material and methods}

\section{Digestibility trials}

The experiment comprised two digestibility trials conducted between May and July. The same sheep were used in both trials.

\section{Animals}

Twelve mature non-breeding healthy ewes of each polled Churra and Merino breeds (24 sheep in total) were used. All animals had been reared under similar conditions in the research farm of the Estación Agrícola Experimental of the Consejo Superior de Investigaciones Científicas (CSIC), located at León in north-west Spain (latitude $42^{\circ} 35^{\prime} \mathrm{N}$; longitude $5^{\circ} 43^{\prime} \mathrm{E}$ ), where the experiment was conducted indoors under natural photoperiod and temperature conditions. Animals were between 3 and 4 years old and their average body weight (BW) was 48.6 (s.e. 1.74) $\mathrm{kg}$ for Churra and 45.9 (s.e. 1.23) $\mathrm{kg}$ for Merino ewes.

\section{Herbage}

During all the experiment ewes were offered fresh herbage harvested from a permanent sward of a mixture of grasses and clover. Herbage was harvested with a mower, chopped to 5 to $10 \mathrm{~cm}$, and stored at $4^{\circ} \mathrm{C}$ in a cold room until use.

Herbage for the first digestibility trial was harvested in late May (early cut, EC), with the plants showing an early vegetative stage, whereas in the second trial the herbage was harvested in late July (late cut, LC) with all the plants at a very mature stage (seeding).
Experimental procedures

Each trial consisted of a preliminary 10-day adaptation period, followed by a 7-day measurement period. During each trial animals were housed in standard metabolism cages in which faeces and urine were collected separately.

In each trial all animals were offered herbage from the same batch, harvested the first day of either the adaptation- or the measurement- period of each balance trial. Therefore, for each trial the herbage was cut and harvested twice: once on the day preceding the commencement of the trial (on 21 May and 10 July for EC and LC, respectively), and again on the day before the measurement period (on 31 May and 20 July for EC and LC, respectively), and then chopped (approx. 5 to $10 \mathrm{~cm}$ ), weighed and stored at $4^{\circ} \mathrm{C}$ in a cold room until required either for the adaptation or for the measurement period, respectively. By cutting at one time all the food required for each particular measurement period, herbage was kept at a specific stage of growth during the whole period, without the variations that would result if fresh herbage was cut every day. Three samples of each batch of herbage were taken during the measurement period and processed for analytical determinations. The chemical composition of the fresh herbage at the two maturity stages was clearly different (Table 1), the EC herbage showing higher crude protein content and lower cell wall content than the LC herbage.

Within each breed of sheep, animals were randomly allocated to different levels of intake, so that digestibility could be determined at six levels of food allowance, with a wide range in dry-matter (DM) intake. Each sheep received a specific amount of fresh herbage, calculated taking into account the animal BW and the herbage DM concentration to reach the intended level of intake. The range in DM intake per $\mathrm{kg}$ BW was the same ( 8.1 to $24.7 \mathrm{~g}$ DM per $\mathrm{kg}$ BW per day) for each breed and in both trials (see Figure 1). Food was distributed to animals twice daily at approximately $09: 00$ and $18: 00 \mathrm{~h}$ as two equal meals. Fresh water and vitamin-mineral blocks were always available. Refusals were weighed out every day so that food intake was calculated as food

Table 1 Chemical composition of the herbage used for each trial

\begin{tabular}{lcc}
\hline \hline & $\begin{array}{c}\text { Early cut } \\
\text { (EC) }\end{array}$ & $\begin{array}{c}\text { Late cut } \\
\text { (LC) }\end{array}$ \\
\hline Cutting date & $31 \mathrm{May}$ & 20 July \\
Dry matter $(\mathrm{DM})(\mathrm{g} / \mathrm{kg})$ & $226 \cdot 0$ & $548 \cdot 1$ \\
Organic matter $(\mathrm{g} / \mathrm{kg} \mathrm{DM})$ & $926 \cdot 3$ & $926 \cdot 4$ \\
Crude protein $(\mathrm{g} / \mathrm{kg} \mathrm{DM})$ & $115 \cdot 8$ & $68 \cdot 8$ \\
Neutral-detergent fibre $(\mathrm{g} / \mathrm{kg} \mathrm{DM})$ & $493 \cdot 5$ & $664 \cdot 1$ \\
\hline \hline
\end{tabular}


offered minus refusals. Samples of refusal were taken for chemical analysis.

Total faecal collection was for the last 5 days of the 7 day measurement period. Faeces of each animal were collected, weighed, thoroughly mixed and sampled $(100 \mathrm{~g} / \mathrm{kg}$ faeces collected) daily. All the aliquots for each sheep were bulked, and the pooled sample was dried to constant weight, ground and stored for chemical analysis. Total daily urinary output was also collected during these 5 days. Urine was collected in a solution of $\mathrm{HCl}(0.2 \mathrm{~mol} / \mathrm{l})$ to maintain the $\mathrm{pH}$ below 3. Daily urine was weighed and its density was measured in order to estimate the volume of liquid excreted. A sample $(20 \mathrm{ml} / 1$ urine collected) was composited daily for each sheep, and stored at $-20^{\circ} \mathrm{C}$ until analysed for purine derivatives.

\section{Rumen degradability}

Samples of each batch of herbage were incubated in the rumen of Churra and Merino sheep by the nylon bags technique (Ørskov and McDonald, 1979) to determine the DM degradability.

Two Churra (mean BW 45 (s.e. 1.3) kg) and two Merino (mean BW 46 (s.e. 1.2) kg) ewes, individually penned and fitted with ruminal cannulae of $35 \mathrm{~mm}$ internal diameter, were used. Each sheep was offered $1 \mathrm{~kg}$ of alfalfa hay per day in two equal meals. For the incubations, bags $\left(12.0 \times 10 \mathrm{~cm}\right.$; Maissa ${ }^{\circledR}$, Spain $)$ made of filter cloth with an approximate pore size of $40 \mu \mathrm{m}$ diameter were used. Samples of $4 \mathrm{~g}$ of dried herbage, ground to pass $2-\mathrm{mm}$ screen, were incubated in the rumen of each of the ewes for $2,4,8$, $16,32,64,96$ and $168 \mathrm{~h}$. One bag per time interval was incubated in each sheep at each of two incubation series, giving two observations per sheep. Bags were introduced into the rumen before the morning meal. After removal from the rumen the bags were rinsed thoroughly under running cold water for $2 \mathrm{~min}$ and then washed for $20 \mathrm{~min}$ with cold water in a commercial washing machine. They were then dried in a forced-air oven at $60^{\circ} \mathrm{C}$ for $48 \mathrm{~h}$ and weighed to determine DM losses. Zero-time losses were estimated by washing two bags per sample with the same washing programme used to wash the bags after the incubations.

\section{Chemical analysis}

Samples of herbage, refusals and faeces were analysed for ash, $\mathrm{N}$ and neutral-detergent fibre (NDF). Procedures described by Association of Official Analytical Chemists (1990) were used to determine organic matter and kjeldahl nitrogen $(\mathrm{N})$. NDF was determined by the method of Goering and Van Soest (1970). Samples of urine were centrifuged at $2500 \mathrm{~g}$ for $5 \mathrm{~min}$ and purine derivatives (allantoin, uric acid, xanthine and hypoxanthine) were analysed by high-performance liquid chromatography according to Balcells et al. (1992). Total purine derivatives (PD) were calculated as the sum of allantoin, uric acid, xanthine and hypoxanthine.

\section{Calculations and statistical analysis}

DM disappearances were fitted to the model described by Ørskov and McDonald (1979) $[D=a+b$ $\left(1-\mathrm{e}^{-c t}\right)$ ], where $D$ represents the loss from the bag after $t h, a$ the instantly degradable fraction, $b$ the slowly degradable fraction and $c$ the rate of degradation of fraction $b$. The equation was fitted to the degradation profiles using the Marquardt method for interactive, non-linear, least-square estimation using the package of Statistical Analysis Systems Institute (SAS, 1993). Extent of degradation of DM in the rumen $(d g ; g / g$ ingested) of sheep was calculated as: $d g=a+b c /(c+k)$, where $k$ is the fractional passage rate (per $h$ ) of digesta from the rumen. The values of $k$ used for the estimation of $d g$ were those given by Ranilla et al. (1998) (0.0424 for Churra and 0.0443 for Merino sheep) measured in animals consuming ca. $1 \mathrm{~kg}$ alfalfa hay daily.

Estimations of the microbial $N$ supply ( $g \mathrm{~N}$ per day) and of the efficiency of microbial N supply (EMNS, g microbial $\mathrm{N}$ per $\mathrm{kg}$ digestible organic matter (OM) apparently digested in the rumen (DOMR)) were obtained from the amount of PD excreted (mmol/ day) following the model derived by Chen et al. (1992).

Data were analysed by standard factorial analysis of variance procedures (Steel and Torrie, 1981) using the SAS package (1993). For the analysis of the data from the rumen degradation trial a factorial design was used, with two sources of variation (2 sheep breeds $\times 2$ herbage maturity stages) and the incubation series as a blocking factor. Total degrees of freedom (15) were partitioned into breed (1), herbage maturity stage (1), interaction breed $\times$ maturity (1), sheep within breed (2) and incubation series (1), leaving 9 d.f. for the error term.

Data from the balance experiment (digestibility and excretion of PD) were analysed following a split-plot design considering animals as the main experimental units and the herbage cutting date (maturity stage) as the repeated measure. Although initially sheep of each breed were randomly assigned to one of six levels of food allowance, actual DM intakes were distributed as a continuous variable and therefore was included in the model as a covariate. Preliminary analyses were performed to examine the homogeneity of the slopes among the different experimental groups. For most variables studied, the 
slope with the covariate was significantly affected by the herbage maturity stage but not by the breed of sheep. Therefore, in those cases a model with separate-slopes for each herbage maturity stage was used. Thus, the factors included in the model were breed (d.f. $=1$ ), animal nested within breed $($ d.f. $=22)$, herbage maturity stage (d.f. $=1$ ), breed $\times$ herbage maturity interaction (d.f. $=1$ ) and intake (as covariate) nested within herbage maturity stage $($ d.f. $=2)$. Animal within breed was the main plot error (Steel and Torrie, 1981) for the comparisons between breeds, whereas the other treatment effects were tested against the overall error $($ d.f. $=20)$. This design implies that data are blocked within individual sheep for statistical comparisons between herbage maturity stages, and therefore the standard errors of difference (s.e.d.) presented in the tables are effective s.e.d. for between- (s.e.d. . $_{\text {) }}$ and within(s.e.d.W) breed comparisons (Steel and Torrie, 1981).

\section{Results}

Digestibility coefficients of herbage at both maturity stages measured in Churra and Merino sheep are shown in Table 2. As expected, apparent digestibility of the herbage was significantly $(P<0.001)$ affected by the maturity stage, with observed mean DM digestibility values of 0.687 and 0.463 for the EC and LC herbage, respectively. The difference between EC and LC herbage was larger for the CP digestibility, due to the low values observed for the LC herbage. Digestibility coefficients observed in Churra ewes tended to be greater than those observed in Merino ewes. However, the differences between breeds did not reach statistical significance $(P>0.05)$ with the EC herbage, whereas with the LC herbage the effect of sheep breed on DM, OM and NDF digestibility was significant $(P<0.05)$.

The effects of herbage maturity stage, sheep breed and level of intake (g DM per kg BW per day) on the apparent DM digestibility are represented in Figure 1. Level of intake was included in the model as a

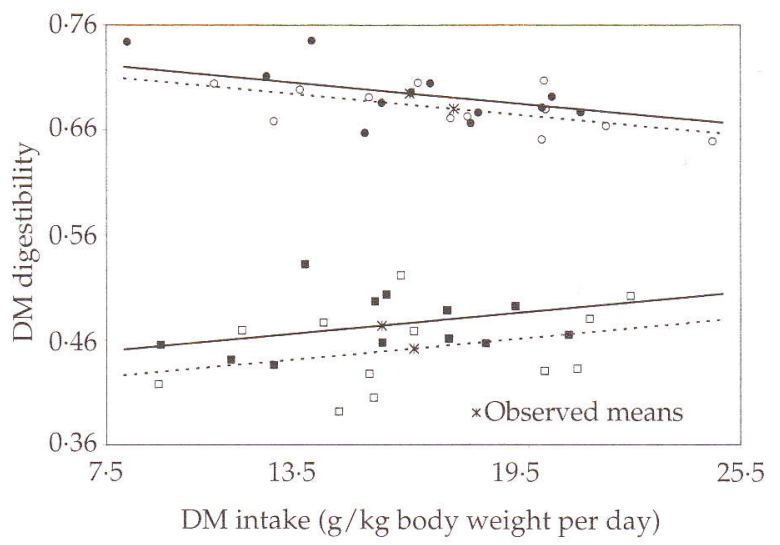

Figure 1 Relationship between dry matter (DM) digestibility of the herbage at two maturity stages (early cut -circles- and late cut -squares-) and level of herbage intake in Churra (solid symbols and lines) and Merino (open symbols and dashed lines) sheep.

covariate with separate slopes for EC and LC herbage. Differences between breeds in DM digestibility were larger with the LC than with the EC herbage. In both breeds, Churra and Merino, DM digestibility of the EC herbage tended to decrease as the level of intake increased (slope $=-0.0031$ (s.e. $0.00155) P<0.05$ ), whereas for the LC herbage, the slope was not significantly different from zero (slope $=0.0030$ (s.e. 0.00195) $P>0.05$ ).

DM disappearance rates from the bags of EC and LC herbage incubated in the rumen of Churra and Merino sheep can be observed in Figure 2. Disappearance rates were greater for EC (Figure 2a) than for LC (Figure 2b) at all incubation times. Within each herbage maturity stage, DM disappearance was higher when the herbage was incubated in the rumen of Churra than in the Merino sheep, with the largest differences between breeds occurring at intermediate incubation times. In both

Table 2 Digestibility coefficients of the herbage at two maturity stages in Churra and Merino sheep

\begin{tabular}{|c|c|c|c|c|c|c|}
\hline & \multicolumn{2}{|c|}{ Early cut (EC) } & \multicolumn{2}{|c|}{ Late cut (LC) } & \multirow[b]{2}{*}{ s.e.d $\mathrm{d}_{\mathrm{B}}$} & \multirow[b]{2}{*}{ s.e.d.w } \\
\hline & Churra & Merino & Churra & Merino & & \\
\hline Dry matter & $0.694^{\text {a }}$ & $0 \cdot 680^{\text {a }}$ & $0.476^{\mathrm{b}}$ & $0.452^{c}$ & 0.0112 & 0.0091 \\
\hline Organic matter & $0.720^{\mathrm{a}}$ & $0.706^{\mathrm{a}}$ & $0.495^{b}$ & $0.472^{c}$ & 0.0109 & 0.0088 \\
\hline Crude protein & $0.663^{a}$ & $0.660^{\mathrm{a}}$ & $0 \cdot 232^{b}$ & $0.223^{b}$ & 0.0137 & 0.0124 \\
\hline Neutral-detergent fibre & $0 \cdot 645^{a}$ & $0 \cdot 621^{a}$ & $0.475^{b}$ & $0.446^{c}$ & 0.0139 & 0.0103 \\
\hline
\end{tabular}

a,b,c Means in a row with different superscripts differ significantly $(P<0.05)$.

s.e.d. ${ }_{B}$ and s.e. $d_{W}$ are standard errors of difference for between- and within-breed comparisons, d.f. 22 and 20 respectively. 
(a) Ruminal degradation of the EC and LC herbage was

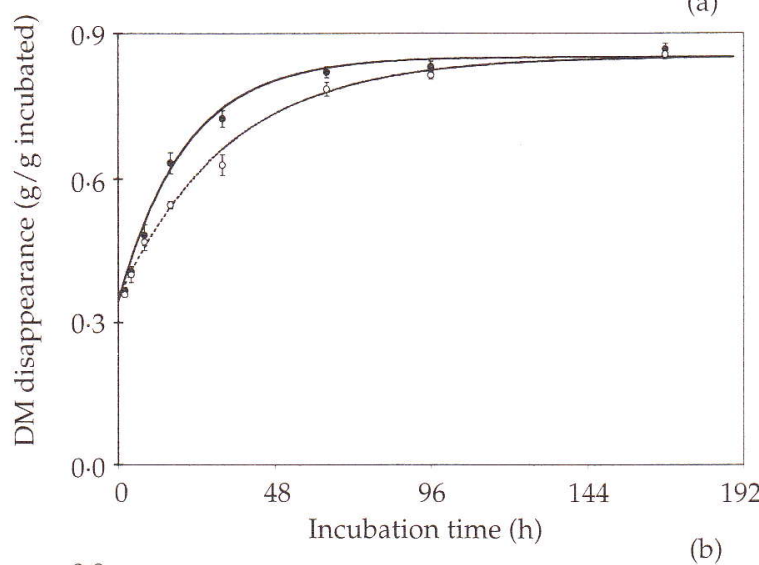
reasonably described by the exponential equation used, with a significant fit $\left(r^{2}>0.95 ; P<0.001\right)$ of the adjusted curves to the observed disappearance rates. The in sacco DM degradation parameters $(a, b, c, a+b$ and $d g$ values) of the EC and LC herbage, in Churra and Merino sheep, are presented in Table 3.

As expected, the rumen potential degradability $(a+b$ value) and the extent of degradation ( $d g)$ of the herbage were significantly $(P<0.05)$ lower for LC than for EC. These effects can be attributed to the large difference between EC and LC in the $a$ parameter, as differences in the $b$ and $c$ parameters were smaller. There were no significant differences $(P>0.05)$ between Churra and Merino breeds in the mean potential degradability values $(a+b)$.

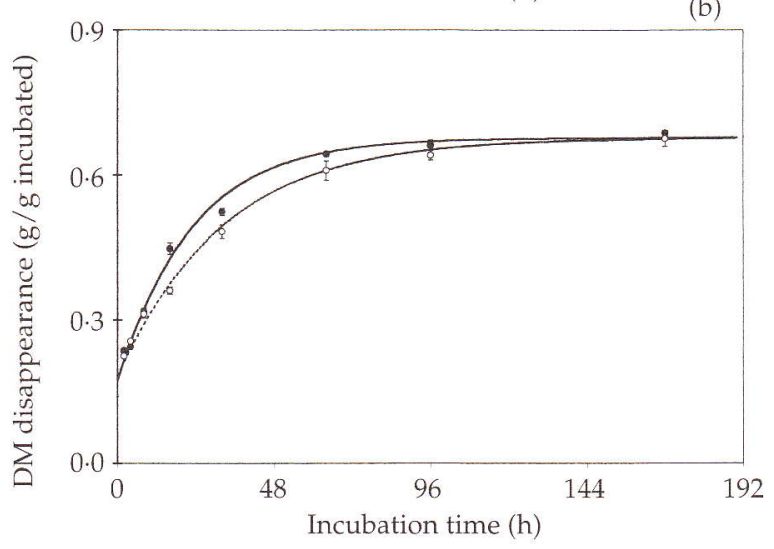

However, the fractional degradation rate (c) was significantly $(P<0.05)$ higher in the Churra than in the Merino sheep $(0.046$ v. 0.031 , respectively). This difference between breeds in the fractional degradation rate of the herbage resulted in a pronounced effect of the sheep breed on the estimated extent of degradation in the rumen $(d g$ value), that was significantly higher in Churra than in Merino sheep for herbage harvested at both maturity stages.

As shown in Table 4 there were significant $(P<0 \cdot 05)$ differences between herbage maturity stages in urinary allantoin and PD excretion, that were greater in EC than in LC herbage. Within each trial, there were no significant $(P>0.05)$ differences between the two groups of animals (Churra $v$. Merino) in the daily excretion of allantoin and total PD in urine. The estimated intestinal flow of microbial $\mathrm{N}$ was significantly $(P<0.05)$ affected by the herbage maturity stage but not by the sheep breed $(P>0.05)$, with similar values for Churra and Merino sheep within each herbage maturity stage. When the microbial $\mathrm{N}$ supply was expressed as $\mathrm{g} \mathrm{N}$ per $\mathrm{kg}$ DOMR, the effects of herbage maturity stage and sheep breed were not significant, and the estimated only reached statistical significance $(P<0.05)$ at 16 , 32 and $64 \mathrm{~h}$ of incubation in the rumen.

Table 3 Dry-matter degradation parameters ( $\mathrm{a}, \mathrm{b}$ and $\mathrm{c}$ values) and extent of rumen degradation ( $\mathrm{dg}$ ) of the herbage at two maturity stages in Churra and Merino sheep

\begin{tabular}{|c|c|c|c|c|c|}
\hline & \multicolumn{2}{|c|}{ Early cut (EC) } & \multicolumn{2}{|c|}{ Late cut (LC) } & \multirow[b]{2}{*}{ s.e.d. } \\
\hline & Churra & Merino & Churra & Merino & \\
\hline$a(\mathrm{~g} / \mathrm{g}$ incubated $)$ & $0 \cdot 319^{\mathrm{a}}$ & $0.337^{b}$ & $0.173^{c}$ & $0.184^{c}$ & 0.0061 \\
\hline$b$ (g/g incubated $)$ & $0.533^{a}$ & $0.516^{\mathrm{ab}}$ & $0.504^{\mathrm{ab}}$ & $0.493^{b}$ & 0.0134 \\
\hline$c$ (per h) & $0.0493^{a}$ & $0.0299^{c}$ & $0.0437^{b}$ & $0.0311^{c}$ & 0.00178 \\
\hline$a+b(\mathrm{~g} / \mathrm{g}$ incubated $)$ & $0.852^{\mathrm{a}}$ & $0.853^{\mathrm{a}}$ & $0 \cdot 678^{b}$ & $0 \cdot 677^{b}$ & 0.0098 \\
\hline$d g(\mathrm{~g} / \mathrm{g}$ ingested $)$ & $0.603^{a}$ & $0.545^{b}$ & $0.428^{c}$ & $0.386^{d}$ & 0.0072 \\
\hline
\end{tabular}

a,b,c,d Means in a row with different superscripts differ significantly $(P<0 \cdot 05)$. 
Table 4 Purine derivative (PD) excretion and estimated microbial nitrogen supply in Churra and Merino sheep given fresh herbage harvested at two maturity stages

\begin{tabular}{|c|c|c|c|c|c|c|}
\hline & \multicolumn{2}{|c|}{ Early cut (EC) } & \multicolumn{2}{|c|}{ Late cut (LC) } & \multirow[b]{2}{*}{ s.e.d. ${ }_{\mathrm{B}}$} & \multirow[b]{2}{*}{ s.e.d. ${ }_{w}$} \\
\hline & Churra & Merino & Churra & Merino & & \\
\hline \multicolumn{7}{|c|}{$\mu \mathrm{mol} / \mathrm{kg}$ body weight per day } \\
\hline Allantoin & $313^{a}$ & $358^{a}$ & $207^{\mathrm{b}}$ & $203^{b}$ & $44 \cdot 4$ & $32 \cdot 4$ \\
\hline Uric acid & $24^{a}$ & $19^{\mathrm{a}}$ & $43^{\mathrm{b}}$ & $24^{\mathrm{a}}$ & $4 \cdot 1$ & $4 \cdot 4$ \\
\hline$X+H$ & $46^{\mathrm{a}}$ & $44^{\mathrm{a}}$ & $48^{\mathrm{a}}$ & $39^{a}$ & 6.9 & $6 \cdot 0$ \\
\hline Total PD & $383^{a}$ & $421^{\mathrm{a}}$ & $298^{\mathrm{b}}$ & $266^{\mathrm{b}}$ & $48 \cdot 3$ & $35 \cdot 6$ \\
\hline \multicolumn{7}{|l|}{$\mathrm{mmol} / \mathrm{day}$} \\
\hline Allantoin & $5.93^{\mathrm{a}}$ & $6 \cdot 36^{a}$ & $2 \cdot 96^{\mathrm{b}}$ & $3 \cdot 60^{\mathrm{b}}$ & 0.952 & 0.681 \\
\hline Total PD & $7 \cdot 23^{a}$ & $7 \cdot 48^{\mathrm{a}}$ & $4 \cdot 60^{\mathrm{b}}$ & $4.79^{\mathrm{b}}$ & $1 \cdot 044$ & 0.758 \\
\hline \multicolumn{7}{|l|}{ Microbial N supply } \\
\hline g N per day & $5 \cdot 79^{a}$ & $6 \cdot 08^{a}$ & $3 \cdot 21^{b}$ & $3.33^{\mathrm{b}}$ & $1 \cdot 027$ & 0.705 \\
\hline $\mathrm{g} N$ per $\mathrm{kg}$ DOMR & $16 \cdot 4^{a}$ & $17 \cdot 2^{a}$ & $17 \cdot 0^{a}$ & $15 \cdot 2^{\mathrm{a}}$ & $2 \cdot 22$ & 1.62 \\
\hline
\end{tabular}

a,b Means in a row with different superscripts differ significantly $(P<0.05)$.

$\mathrm{X}+\mathrm{H}=$ xanthine + hypoxanthine.

DOMR = digestible organic matter apparently digested in the rumen.

s.e.d. ${ }_{B}$ and s.e.d. ${ }_{W}$ are standard errors of difference for between- and within-breed comparisons, d.f. 22 and 20 respectively.

efficiencies of microbial supply were similar in all experimental groups (Table 4).

The effects of DM intake ( $\mathrm{g} /$ day) on microbial $\mathrm{N}$ supply and EMNS are illustrated in Figure $3 a$ and b, respectively. The test of homogeneity of slopes revealed that the relationship between these variables was not significantly affected by the herbage maturity stage or by the sheep breed, so a common slope was used to represent that relationship in all experimental groups. Two regression lines were used for the relationship between microbial $\mathrm{N}$ supply and DM intake, given that average values of microbial $\mathrm{N}$ supply were significantly greater for EC than for LC herbage, and therefore the intercept of the regression equation (Figure 3a) was also higher for EC than for LC herbage. The microbial $\mathrm{N}$ supply and EMNS were both linearly related to the daily DM intake expressed per $\mathrm{kg}$ BW. The slopes of these relationships were 0.495 (s.e. $0.0767 ; P<0.001$ ), and 0.496 (s.e. $0.2224 ; P<0.05$ ) for the microbial $\mathrm{N}$ and for EMNS, respectively; indicating that both variables were higher as the DM intake was increased.

\section{Discussion}

Herbage maturity stage

Herbage maturity stage at harvest is one of the main factors affecting the nutritive value of the forage obtained from permanent swards like that used in this study. As the cutting date is delayed the botanical composition of the herbage changes significantly, increasing the proportion of grasses and decreasing the relative proportion of legumes (clover). Other changes with a later plant maturity stage are the decrease in the leaf to stem ratio and the development of supporting tissues, characterized by the presence of highly lignified cell walls. Therefore, the $\mathrm{N}$ content of the herbage decreases with maturity, whereas the cell wall concentration is increased (Van Soest, 1994). Herbage digestibility decreases with plant maturity stage (Minson, 1990; Demarquilly et al., 1995), and therefore digestibility of EC herbage was significantly greater than that of LC herbage. The contribution of endogenous material to the total faecal excretion should be greater with the LC than with the EC herbage (Van Soest, 1994; Demarquilly et al., 1995), as mirrored in the differences between the two in apparent digestibility, especially of CP.

The differences between the two trials in the microbial $\mathrm{N}$ supply should be attributed to the higher $\mathrm{N}$ content and digestible OM intake of the EC compared with the LC herbage, resulting in higher degradable $\mathrm{N}$ and fermentable OM supply for the microbial synthesis in the rumen. However, the efficiency of microbial synthesis seemed to be not affected by herbage maturity stage, as EMNS estimated from PD excretion was similar in both trials. Beever et al. (1986) found no evidence of forage-induced or season-induced effects on the efficiency of microbial $\mathrm{N}$ synthesis measured in vivo in cattle given either ryegrass or white clover harvested at three maturity stages.

Herbage maturity stage would induce changes in neither the type of $\mathrm{N}$ and energy sources reaching the rumen nor their rates of release in the rumen (Sinclair et al., 1995; Dijkstra et al., 1998), explaining 
(a)

14.0

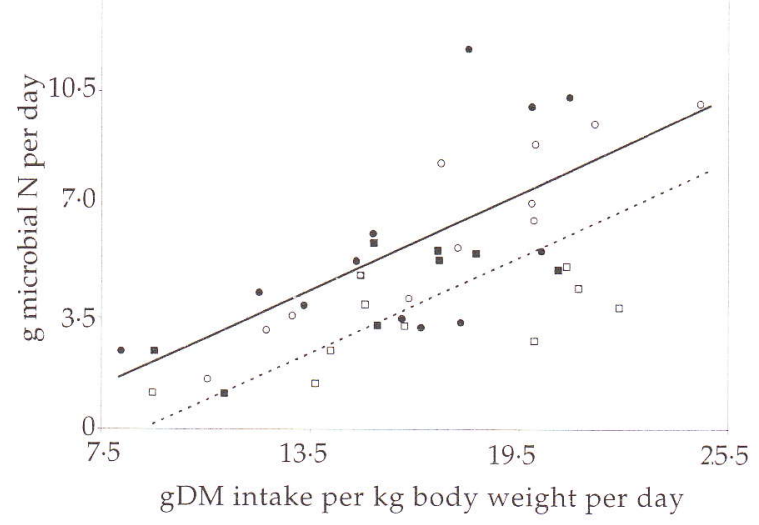

(b)

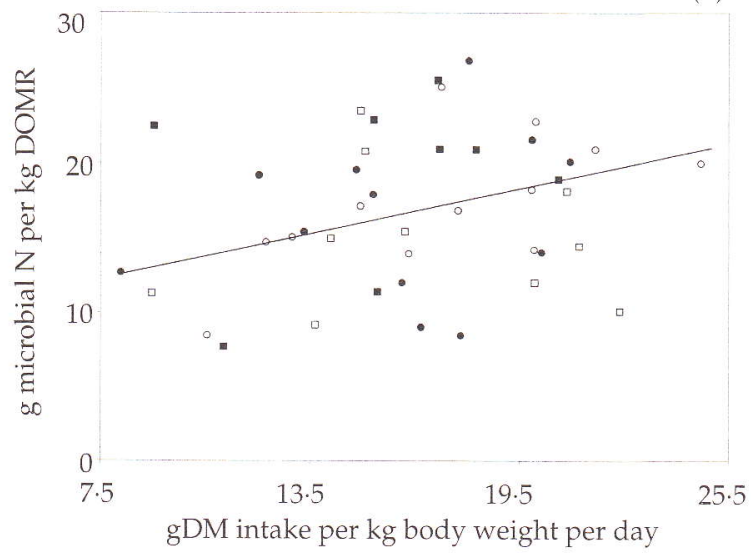

Figure 3 Relationships between the estimated microbial nitrogen supply expressed as (a) g N per day or (b) g N per $\mathrm{kg}$ DOMR (digestible organic matter apparently digested in the rumen) in Churra (solid symbols) and Merino (open symbols) sheep and level of intake of herbage harvested at two maturity stages (early cut-EC, circles- and late cut -LC, squares-).

therefore the lack of response in the efficiency of microbial N synthesis.

\section{Breed of sheep}

Differences between breeds and genotypes of sheep in many aspects of their basic biology (reproduction, lactation and growth) are well known. Nevertheless, differences between breeds in the digestibility and rumen degradability of foods have only been investigated more recently, with controversial results. Thus, whereas some authors have detected significant differences between breeds of sheep in the digestibility of forage diets (Amor, 1994; Givens and Moss, 1994; Manzke et al., 1997; Lourenço et al., 2000), others have found negligible differences (Ranilla et al., 1998). Iason et al. (1995) observed that the apparent digestibility of timothy hay was significantly lower in Shetland than in Dorset Horn and Scottish Blackface sheep. None the less, when the experiment was repeated in a different trial, using the same hay, the digestibility was not different among the three breeds any more.

Several in situ and in vitro experiments have also been carried out to study differences between breeds in the rumen degradability of foods. In general, degradability was greater in the rumen of local breeds than in the rumen of non-native and/or improved breeds (De Waal, 1995; Ranilla et al., 1997; Manso et al., 1999; Šebek and Everts, 1999). Ranilla et al. (1997 and 2000) found that rumen degradability of some feeds was higher in Churra than in Merino sheep, although these differences between breeds were larger with foods with a higher cell wall concentration and insignificant with some other feeds. In contrast with previous work, Ranilla et al. (2000) reported higher rumen degradability of oesophageal extrusa from Merino than from Churra sheep, and explained these differences on the basis of the improved ability of Merino sheep to select their diet. In this case, the material incubated in the rumen of Churra and Merino sheep would not be the same, as that selected by Merino sheep would be of better quality.

Therefore, differences between breeds in the digestion and rumen degradation of foods seem to be dependent upon the breeds studied and on the type of food used for the comparison. The differences are more pronounced between breeds adapted to different environmental and feeding conditions (Weyreter and Engelhardt, 1984; Mann et al., 1987; Givens and Moss, 1994), as changes in digestive ability would have been evolved in response to the adaptation to marginal situations. Breeds will differ more in the digestion of poor quality foods, for which local breeds would be more adapted compared with those improved breeds given good quality foods to increase their productivity. Ranilla et al. (1998) and Lourenço et al. (2000) concluded that differences between breeds in the digestive utilization of foods are only noticeable with poorquality forages offered at levels close to ad libitum intake.

As stated in the Introduction, the main objective of the present work was to study breed differences using forages of different digestibilities offered at different levels of intake. The differences between the Churra and the Merino sheep were not affected by food intake. However, herbage quality seemed to have an important effect on the comparison. 
Differences between breeds were not significant when animals were given the early cut, highly digestible herbage but reached statistical significance with the late cut, poorly digestible herbage. Although both Churra and Merino breeds are autochthonous breeds, they have been traditionally managed in different sheep production systems and therefore adapted to different feeding conditions. Merino sheep have been managed in a transhumance system following pasture allowance. This system may have induced a selection towards sheep that select the best herbage on offer and, therefore, the digestion of highly digestible roughage. On the other hand, Churra sheep have been managed in a nonmigratory system, typical of semi-arid upland areas, in which they are grazed at some periods of the year on very low-quality food resources such as stubble.

The ability of some breeds to digest more fibrous foods has been attributed to changes in the rumen environment (Ranilla et al., 1997 and 2000; Manzke et al., 1997) that enhance their cellulolytic activity in the rumen. Ranilla et al. (1997) observed that ruminal pH was more stable and remained longer within a range of values more favourable for the digestion of fibre in Churra than in Merino sheep, probably due to higher rates of saliva secretion (Ranilla et al., 1998).

Other digestive mechanisms that would allow a more efficient digestion of fibrous diets by some breeds have been suggested, such as increasing the volume of the reticulo-rumen, prolonging the retention time of fluid and particles (Weyreter and Engelhardt, 1984; Ranilla et al., 1998), facilitating a greater reduction in particle size and increased saliva production by more intense chewing and ruminating (Šebek and Everts, 1999) or changing the protozoal population in the rumen in response to the diet (Teferedegne et al., 1999). The differences between breeds in herbage digestibility were similar over the whole range of DM intakes, as the interaction between breed and level of intake was not statistically significant. It is noteworthy that breed differences were larger for rumen degradability measured in situ than for in vivo digestibility, indicating that there could be some differences in the digestion in the hindgut, and that generalizing in situ results to an in vivo situation should be done with care.

Despite the differences between Churra and Merino sheep in the rumen degradation of the herbage, no significant differences between breeds were detected in the microbial $\mathrm{N}$ flow to the intestine or in the efficiency of microbial $N$ supply, which is in agreement with similar comparisons reported by other authors (Ranilla et al., 1998; Lourenço et al.,
2000). It is possible that this indirect method of estimating microbial $N$ supply is not sensitive enough to detect slight differences between treatments, given the large individual variability in the PD urinary excretion (Chen et al., 1992). The values observed in both breeds were in the range of those reported previously for forage diets (Chen et al., 1992), although some values of microbial $N$ supply per $\mathrm{kg}$ DOMR were lower than average values of efficiency of microbial $\mathrm{N}$ synthesis reported in the literature (Jouany et al., 1995), suggesting that either $\mathrm{N}$ or energy may have been limiting for microbial growth.

\section{Food intake}

Higher levels of intake of a particular roughage have been associated with reduced digestibility, due to the more rapid passage of digesta from the rumen (Balch and Campling, 1962; Demarquilly et al., 1995), thus reducing the time available for ruminal microbial digestion (Owens and Goetsch, 1986). Although this relationship between roughage digestibility and DM intake has been generally accepted (Faichney, 1986), there are a number of studies in sheep in which the reduction in intake or the increase in retention time of digesta in the rumen were not accompanied by consistent increases in digestibility of roughage diets (Blaxter et al., 1956; Grovum and Williams, 1977; Iason et al., 1995). In the present experiment, higher $\mathrm{DM}$ intakes resulted in a slight decrease in digestibility only with the early cut herbage, whereas no significant relationship between DM intake and digestibility was found with the low-digestibility herbage (Figure 1).

The cause and effect of the association between intake and digestibility has been questioned (Warner, 1981), owing to the controversial results reported in the literature (Demarquilly et al., 1995). It is possible that long roughage diets as in this experiment have relatively long retention times in the rumen, enough for the microbial action. The reduction in retention time in the rumen associated with higher intakes can be followed by compensatory shifts in the site of digestion, so that more food is digested in the hindgut (Grovum and Williams, 1977), and the digestibility in the whole tract is not significantly affected.

Finally, higher passage rates have been associated with a higher efficiency in the microbial growth in the rumen (Owens and Goetsch, 1986; Chen et al., 1992), and hence with faster degradation rates that would compensate for the effect of shorter retention times. In the present study, a highly significant relationship between DM intake and microbial $\mathrm{N}$ supply (Figure 3a) was observed. This relationship is 
not solely determined by the amount of food consumed. The efficiency of microbial synthesis (as $\mathrm{g}$ microbial $\mathrm{N}$ supply per $\mathrm{kg}$ digestible $\mathrm{OM}$ ) is also increased with higher DM intakes (Figure 3b), increasing the outflow of microbial mass from the rumen. This is in agreement with the relationship reported by Chen et al. (1992), although these authors observed higher efficiencies of microbial supply by feeding the sheep with a good quality diet.

In conclusion, comparisons between sheep breeds in digestibility are highly dependent on the diet, demonstrating that there is no common explanation to elucidate the differences between breeds in the digestibility of roughages. In the present study, the differences between Churra and Merino sheep were more pronounced with the low-digestibility herbage. Digestibility of LC herbage was greater in Churra than in Merino sheep, whereas there were no significant differences between breeds in the digestibility of the EC herbage. Breed differences were not affected by the level of intake. The relationship between digestibility and intake was not consistent, as there may be a multiplicity of factors acting in one or another sense. In particular, the increase in food intake led to a higher supply of microbial mass to the small intestine, indicating that could increase the efficiency of microbial synthesis in the rumen.

\section{Acknowledgements}

Financial support received from Comisión Interministerial de Ciencia y Tecnología of Spain (Project AGF98-0188) is gratefully acknowledged.

\section{References}

Association of Official Analytical Chemists. 1990. Official methods of analysis of the Association of Official Analytical Chemists, 15th edition. Washington, DC.

Amor, J. J. 1994. [Diurnal patterns of intake and rumination in sheep as affected by different factors.] Tesis doctoral, Universidad de León.

Balcells, J., Guada, J. A., Peiró, J. M. and Parker, D. S. 1992. Simultaneous determination of allantoin and oxipurines in biological fluids by high-performance liquid chromatography. Journal of Chromatography 575: 153-157.

Balch, C. C. and Campling, R. C. 1962. Regulation of voluntary food intake in ruminants. Nutrition Abstracts and Reviews 32: 669-686.

Beever, D. E., Dhanoa, M. S., Losada, H. R., Evans, R. T., Cammell, S. B. and France, J. 1986. The effect of forage species and stage of harvest on the processes of digestion occurring in the rumen of cattle. British Journal of Nutrition 56: $439-454$.

Blaxter, K. L., Graham, N. McC. and Wainman, F. W. 1956. Some observations on the digestibility of food by sheep, and on related problems. British Journal of Nutrition 10: 69-91.
Chen, X. B., Chen, Y. K., Franklin, M. F., Ørskov, E. R. and Shand, W. J. 1992. The effect of feed intake and body weight on purine derivative excretion and microbial protein supply in sheep. Journal of Animal Science 70: 1534-1542.

De Waal, H. O. 1995. In sacco dry matter disappearance of herbage and maize meal from the rumen of lactating Dorper and Merino ewes supplemented with protein and energy on native pastures. South African Joumal of Animal Science 25: 1-6.

Demarquilly, C., Chenost, M. and Giger, S. 1995. Pertes fécales et digestibilité des aliments et des rations. In Nutrition des ruminants domestiques. Ingestion et digestion (ed. R. Jarrige, Y. Ruckebusch, C. Demarquilly, M.-H. Farce and M. Journet), pp. 601-647. INRA, Paris.

Dijkstra, J., France, J. and Davies, D. R. 1998. Different mathematical approaches to estimating microbial protein supply in ruminants. Journal of Dairy Science 81: 3370-3384.

Dulphy, J.-P., Balch, C. C. and Doreau, M. 1995. Adaptation des espèces domestiques à la digestion des aliments lignocellulosiques. In Nutrition des ruminants domestiques. Ingestion et digestion (ed. R. Jarrige, Y. Ruckebusch, C Demarquilly, M.-H. Farce and M. Journet), pp. 759-803. INRA, Paris.

Faichney, G. J. 1986. The kinetics of particulate matter in the rumen. In Control of digestion and metabolism (ed. L. P. Milligan, W. L. Grovum and A. Dobson), pp. 173-195. Prentice-Hall, Englewood Cliffs, NJ.

Frutos, P., Revesado, P. R., Mantecón, A. R., González, J. S. and Carro, M. D. 1992. Proportion of digestive tract: a comparison of two Spanish sheep genotypes (Churra vs. Merina). Nutrition Clinique et Métabolisme 6: 173-174.

Frutos, P., Wright, I. J., Giráldez, F. J., Mantecón, A. R. and Iason, G. 1998. Seasonal variation in nutrition and supplementation in sheep extensive systems in northcentral Spain. In The implications of extensification for the health and welfare of beef cattle and sheep (ed. P. Goddard), proceedings of a workshop held in Aberdeen (UK), pp. 17-23.

Givens, D. I. and Moss, A. R. 1994. Effect of breed, age and body condition of sheep on the measurements of apparent digestibility of dried grass. Animal Feed Science and Technology 46: 155-162.

Goering, H. K. and Van Soest, P. J. 1970. Forage fiber analysis (apparatus, reagents, procedures and some applications). Agriculture handbook, no. 379. Agricultural Research Service, USDA, Washington, DC.

Grovum, W. L. and Williams, V. J. 1977. Rate of passage of digesta in sheep. 6 . The effect of level of food intake on mathematical predictions of the kinetics of digesta in the reticulorumen and intestines. British Tournal of Nutrition 38: 425-436.

Iason, G. R., Sim, D. A. and Foreman, E. 1995. Seasonal changes in intake and digestion of chopped timothy hay (Phleum pratense) by three breeds of sheep. Journal of Agricultural Science, Cambridge 125: 273-280.

Jouany, J.-P., Broudiscou, L., Prins, R. A. and Komisarczuk-Bony, S. 1995. Métabolisme et nutrition de la population microbienne du rumen. In Nutrition des ruminants domestiques. Ingestion et digestion (ed. R. Jarrige, Y. Ruckebusch, C. Demarquilly, M. -H. Farce and M. Journet), pp. 349-381. INRA, Paris. 
Lourenço, A. L. G., Dias-da-Silva, A. A., Fonseca, A. J. M. and Azevedo, J. T. 2000. Effects of live weight, maturity and genotype of sheep fed a hay-based diet, on intake, digestion and live weight gain. Livestock Production Science 63: 291-296

Mann, D. L., Goode, L. and Pond, K. R. 1987. Voluntary intake, gain, digestibility, rate of passage and gastrointestinal tract fill in tropical and temperate breeds of sheep. Journal of Animal Science 64: 880-886.

Manso, T., Castro, T., Mantecón, A. R., Rodríguez, G. and Falagán, A. 1999. [Rumen degradation of shrub communities from semi-arid lands in the Southeast of Spain in two sheep genotypes (Segureña vs. Merino).] Archivos de Zootecria 48: 95-100.

Manzke, V., Munchow, H., Betzin, B. and Hasselmann, I. 1997. Investigations of digestive and metabolic mechanisms of adaption of several breeds of sheep and goats to malnutritional conditions. International Joumal of Mammalian Biology 62: 124-128.

Minson, D. J. 1990. Forage in ruminant nutrition. Academic Press, London.

Ørskov, E. R. and McDonald, I. 1979. The estimation of protein degradability in the rumen from incubation measurements weighed according to rate of passage. Journal of Agricultural Science, Cambridge 92: 499-503.

Owens, F. N. and Goetsch, A. L. 1986. Digesta passage and microbial protein synthesis. In Control of digestion and metabolism (ed. L. P. Milligan, W. L. Grovum and A. Dobson), pp. 196-223. Prentice-Hall, Englewood Cliffs, NJ.

Ranilla, M. J., Carro, M. D., Giráldez, F. J., Mantecón, A. R. and González, J. S. 2000. Comparison of rumen fermentation patterns and in situ degradation of grazed herbage in Churra and Merino sheep. Livestock Production Science 62: 193-204

Ranilla, M. J., Carro, M. D., Valdés, C., Giráldez, F. J. and López, S. 1997. A comparative study of ruminal activity in Churra and Merino sheep offered alfalfa hay. Animal Science 65: 121-128.

Ranilla, M. J., López, S., Giráldez, F. J., Valdés, C. and Carro, M. D. 1998. Comparative digestibility and digesta flow kinetics in two breeds of sheep. Animal Science 66: 389-396.

Revesado, P. R., Mantecón, A. R., Frutos, P. and González, J. S. 1994. Comparative studies of diet selection by Churra and Merina genotypes grazing on a hill shrub community. In Livestock production and land use in hills and uplands (ed. T. L. J. Lawrence, D. S. Parker and P. Rowlinson) British Society of Animal Production occasional publication no. 18, pp. 109-110.

Šebek, L. B. J. and Everts, H. 1999. In situ rumen degradation of dry matter and crude protein in ewes and dairy cows. Animal Science 68: 801-808.

Sinclair, L. A., Garnsworthy, P. C., Newbold, J. R. and Buttery, P. J. 1995. Effects of synchronizing the rate of dietary energy and nitrogen release in diets with a similar carbohydrate composition on rumen fermentation and microbial protein synthesis in sheep. Journal of Agricultural Science, Cambridge 124: 463-472.

Statistical Analysis Systems Institute. 1993. SAS companion for the Microsoft Windows environment, version 6. SAS Institute Inc., Cary, NC.

Steel, R. G. C. and Torrie, J. H. 1981. Principles and procedures of statistics, second edition. McGraw-Hill, New York.

Teferedegne, B., McIntosh, F., Osuji, P. O., Odenyo, A. Wallace, R. J. and Newbold, C. J. 1999. Influence of foliage from different accessions of the sub-tropical leguminous tree, Sesbania sesban, on ruminal protozoa in Ethiopian and Scottish sheep. Animal Feed Science and Technology 78: 11-20.

Van Soest, P. J. 1994. Nutritional ecology of the ruminant, second edition. Cornell University Press, Ithaca, New York.

Warner, A. C. I. 1981. Rate of passage of digesta through the gut of mammals and birds. Nutrition Abstracts and Reviews 51: 789-820.

Weyreter, H. and Engelhardt, W. v. 1984. Adaptation of Heidschnucken, Merino and Blackhead sheep to a fibrous diet of poor quality. Canadian Journal of Animal Science 64: (suppl.) 152-153.

(Received 20 September 2000-Accepted 14 May 2001) 